\title{
IMPLEMENTASI HAK POLITIK MANTAN NARAPIDANA KORUPSI DALAM PEMILIHAN UMUM DI JAWA TIMUR
}

\author{
Muwahid \\ UIN Sunan Ampel Surabaya | Jl. A. Yani I I7 Surabaya| \\ muwahidizza@gmail.com
}

\begin{abstract}
The right to be voted and to be elected is a human right guaranteed by the Constitution. However, there are limitations to implementation. Research on the implementation of the political rights of ex-convicts in the general election aims to address the problem; first, regulations on the rights of former corruption convicts to be elected in legislation. Second, Implementation of the rights of elected ex-convicts of corruption in the election after the decision of the Supreme Court in East Java. This research is empirical legal research or socio-legal research. The Data obtained through document studies and subsequently, the interviews analyzed with an existing legal theory with a statute approach and a case approach. Data analysis techniques are using inductive thinking patterns. The results of this study indicate that the political rights of exconvicted corruption are guaranteed in article 28 letter D point 3 of the 1945 Constitution, and article 43 of Law No. 39 of 1999 concerning Human Rights and the Election Law, where everyone has the right to be elected and to vote in elections based on the principle of equality. However, in its implementation, there are several variants such as the General Election Commission which issued a regulation prohibiting excorruption convicts from running, even though the regulation was canceled by the Supreme Court. Likewise, some political parties consistently did not nominate members who have been exposed to corruption as a preventive measure in preventing corruption.
\end{abstract}

Key Word: Political Right, General Elections.

Abstrak: Hak untuk memilih dan dipilih merupakan hak asasi yang dijamin oleh Konstitusi. Namun demikian terdapat pembatasan-pembatasan dalam pelaksanaanya. Penelitian tentang implementasi hak politik mantan 
narapidana dalam pemilu bertujuan untuk menjawab permasalahan; I . Pengaturan hak dipilih mantan narapidana korupsi dalam peraturan perundang-undangan; 2. Implementasi hak dipilih mantan narapidana korupsi dalam pemilu pasca putusan Mahkamah Agung di Jawa Timur. Penelitian ini merupakan peneltian yuridis empiris atau penelitian sosio legal research. Data diperoleh melalui studi dokumen dan wawancara selanjutnya dianalisis dengan teori hukum yang ada dengan pendekatan perundang-undangan (statute approach), dan pendekatan kasus (cases approach). Teknik analisa data menggunakan pola fikir induktif. Hasil penelitian ini menunjukkan bahwa Hak politik mantan terpidana korupsi dijamin di dalam pasal 28 huruf D poin 3 UUD 1945, dan pasal 43 Undang-undang No. 39 tahun 1999 tentang Hak Asasi Manusia dan Undang-undang Pemilu, dimana setiap orang mempunya hak untuk dipilih dan memilih dalam pemilihan umum berdasarkan asas persamaan hak. Namun demikian dalam implementasinya terdapat beberapa varian misalnya Komisi Pemilihan Umum yang mengeluarkan peraturan yang melarang mantan narapidana korupsi untuk mencalonkan diri, meskipun peraturan itu dibatalkan oleh Mahkamah Agung. Demikian pula beberapa partai politik konsisten tidak mencalonkan anggotanya yang pernah terkena kasus korupsi sebagai upaya preventif dalam pencegahan tindak pidana korupsi.

Kata Kunci: Hak Asasi, Pemilihan umum.

\section{Pendahuluan}

Dalam sebuah negara yang demokratis, pemilu merupakan sarana untuk mewujudkan kedaulatan rakyat, yang ikut terlibat aktif dalam penyelenggaraan pemilihan umum baik untuk memilih maupun dipilih.Tujuan pemilihan umum yang dilaksanakan adalah untuk untuk membentuk pemerintahan yang demokratis melalui mekanisme pemilu yang jujur dan adil. ${ }^{1}$ Negara-negara yang menganut sistem demokrasi, pemilu dijadikan tolak ukur bagi pelaksanaan demokrasi. ${ }^{2}$ Prinsip utama dalam sistem demokrasi

\footnotetext{
I Ahmad Zazili, "Pengakuan Negara Terhadap Hak-hak Politik (Rigth to Vote) Masyarakat Adat Dalam Pelaksanaan Pemilihan Umum". Jurnal Konstitusi Vol 9 Nomor I, Maret 20 I 2, I 36.

2 Mirriam Budiardjo, Dasar-dasar Ilmu Politik, (Jakarta: Gramedia Pustaka, 2009), 46 I.
} 
adalah setiap orang berhak aktif dalam proses politik, baik hak untuk dipilih maupun hak untuk memilih. ${ }^{3}$

Konstitusi Republik Indonesia mengamanatkan setiap warga Negara mempunyai hak yang sama untuk menduduki jabatan di pemerintahan.Itu mengisyaratkan bahwa setiap warga Negara mempunyai hak untuk memilih dan dipilih dalam pemilihan umum. Namun dalam kenyataanya tidak sebagaimana yang diamanatkan oleh konstitusi, ada pembatasan-pembatasan yang dilakukan oleh pembentuk undang-undang. Pembatasan itu misalnya adanya ketentuan dalam Undang-undang Pemilu yang mensyaratkan calon anggota DPR/DPRD tidak pernah mendapatkan hukuman penjara dalam kasus korupsi.

Hak untuk dipilih dalam pemilihan umum merupakan hak yang dijamin dalam konstitusi (UUD NRI 1945), sebagaimana yang tercantum dalam Pasal 28 huruf D yang berbunyi: "setiap orang berhak memperoleh kesempatan yang sama dalam pemerintahan". Ketentuan dalam Pasal 28 huruf D UUD NRI 1945 tersebut dalam pelaksanaanya dinegasikan oleh Undang-undang Nomor 8 Tahun 2015 tentang pemilu dan pemilukada, yang mensyaratkan bahwa calon gubenur, bupati, walikota, tidak pernah mendapatkan hukuman dengan ancaman hukuman 5 tahun penjara sebagiamana diatur dalam Pasal 7 huruf g yang menyatakan sebagai berikut:

“...Warga Negara Indonesia yang dapat menjadi calon Gubernur, Calon Bupati, Calon Wali Kota adalah yang memenuhi syarat diantaranya; (g). tidak pernah dijatuhi pidana penjara berdasarkan putusan pengadilan yang telah memperoleh kekuatan hukum yang tetap karena melakukan tindak pidana yang diancam dengan pidana penjara 5 (lima) tahun atau lebih..".

Pasal 7 huruf $g$ di atas kemudian dibatalkan oleh Mahkamah Konstitusi dalam Putusannya NomorNo. 42/PUU-XIII/2015 yang memberikan hak bagi mantan narapidana untuk mencalonkan diri

3 Dahlan Thaib, Implementasi Sistem Ketatanegaraan Menurut UUD 1945, (Yogyakarta, Pustaka Pelajar, 1993), 94. 
sebagai calon kepala daerah, baik calon Gubernur, Bupati atau Walikota.

Berdasarkan putusan Mahkamah Konstitusi tersebut, kemudian dibuat perubahan Undang-undang Pemilu yang menyangkut masalah hak mantan narapidana sebagaimana diatur dalam Pasal 182 ayat (1) huruf g Undang-undang No. 7 Tahun 2017 menyatakan bahwa: "mantan narapidana yang telah menjalani masa hukuman selama lima tahun atau lebih, boleh mencalonkan diri selama yang bersangkutan mengumumkan pernah berstatus sebagai narapidana kepada publik".

Namun demikian, pada tahun 2018 Komisi Pemilihan Umum (KPU) membuat Peraturan KPU No. 20 Tahun 2018 Pasal 4 ayat (3) yang menyatakan bahwa "Dalam seleksi bakal calon secara demokratis dan terbuka sebagaimana dimaksud pada ayat (2), tidak menyertakan mantan terpidana bandar narkoba, kejahatan seksual terhadap anak, dan korupsi". Larangan yang tertuang dalam peraturan KPU tersebut di satu sisi sebagai upaya preventif dalam pemberantasan korupsi. Namun pada sisi yang yang lain peraturan KPU tersebut bertentangan dengan Hak Asasi Manusia yang dijamin oleh kontitusi, yakni setiap orang mempunya hak untuk memilih dan dipilih dalam pemilihan umum. Selain itu, pembatalan pasal tersebut yang dilakukan oleh MA karena juga dinilai bertentangan dengan Pasal 182 ayat (1) huruf g Undang-undang No. 7 Tahun 2017.

Sementara pihak partai politik sendiri dalam menyikapi Peraturan KPU dan putusan MA berbeda-beda, dari 16 partai politik yang ada hanya 4 partai politik yang konsisten tidak mencalonkan mantan narapidana korupsi dalam Pemilu 2019. Fokus utama pembahasan dalam penelitian ini adalah; pertama, pengaturan hak dipilih mantan narapidana korupsi dalam pemilihan umum dalam perundang-undangan; kedua, implementasi hak dipilih mantan narapidana korupsi dalam pemilu 2019 pasca putusan Mahkamah Agung (MA) di Jawa Timur. 


\section{Pemilihan Umum}

Dalam sebuah Negara yang demokratis, proses pergantian kepimpinan nasional selalu dilakukan dengan mekanisme pemilihan umum sebagai sarana untuk mewujudkan kedaulatan rakyat. Dengan pemilu yang bebas, jujur dan adil rakyat menentukan pilihanya melalui mekanisme yang ada. Pemilu sebagai sarana untuk mewujudkan demokrasi harus tunduk dan patuh pada aturan hukum yang ada, ini yang disebut sebagai demokrasi yang berlandaskan hukum atau demokrasi konstitusional (constitusional democracy). ${ }^{4}$ Dengan sistem demokrasi rakyat diberikan hak yang seluas-luasnya untuk ikut menentukan arah kebijakan Negara melalui wakilnya yang duduk di parlemen yang dipilih melalui mekanisme pemilihan umum yang jujur dan adil.

Pemilu sebagai sarana perwujudan demokrasi memberikan hak kepada rakyat untuk dapat memilih dan atau dipilih secara demokratis dalam rentan waktu lima tahunan. Dengan pemilu yang jujur dan adil akan dapat melahirkan sistem pemerintahan yang demokratis. ${ }^{5}$ Dengan adanya pemilu hak untuk dipilih dan memilih dapat diimplementasikan dalam sistem pemilu yang jujur dan adil. Hak untuk dipilih secara implisit dapat ditemukan dalam Konstitusi Pasal 28 huruf D, bahwa setiap orang mempunyai hak yang sama untuk duduk di pemerintahan. Untuk menduduki jabatan-jabatan tertentu di pemerintahan dapat dilalui dengan mekanisme pemilihan umum yang dilaksanakan lima tahun sekali. Salah satu jabatan yang diperoleh dalam pemelihan umum adalah menjadi anggota DPR, DPD, dan DPRD. Dengan demikian pada dasarnya pemilihan umum merupakan sarana untuk mewujudkan prinsip-prinsip demokrasi yang dilakukan secara jujur dan adil.

\footnotetext{
4 Bisarida et all, "Komparasi Mekansime Penyelesaian Sengketa Pemilu di Beberapa Negara Penganut Paham Demokrasi,", Jurnal Konstitusi, Volume 9, Nomor 3, September 20 I 2, 539-540. ${ }^{5}$ Ahmad Zazili, Pengakuan Terhadap...., 136.
} 


\section{Hak Asasi Manusia}

Salah satu ciri dari negara hukum adalah adanya pengakuan dan perlindungan terhadap hak asasi manusia. ${ }^{6}$ Pasal 1 ayat (3) UUD NRI 1945 secera ekplisit menyatakan bahwa Indonesia adalah negara hukum, sebagai sebuah negara hukum yang moderen merupaka sebuah kewajiban untuk mencantumkan secara eksplisit pengakuan dan perlindungan terhadap hak asasi manusia di dalam konstitusi.7 Dalam konstitusi Indonesia pengakuan terhadap hak asasi manusia dicantumkan dalam Pasal 28 A sampai dengan Pasal 28 J UUD NRI 1945.

Selain diatur dalam konstitusi hak asasi manusia sebagai hak dasar yang dimiliki oleh setiap orang sejak ia dilahirkan, ${ }^{8}$ juga diatur secara khusus dalam Undang-undang Nomor 39 Tahun 1999 tentang Hak Asasi Manusia. Pasal 1 ayat (1) memberikan pengertian yang jelas mengenai hak asasi manusia sebagai "hak yang melekat pada hakekat dan keberadaan manusia sebagai makluk Tuhan Yang Maha Esa dan merupakan anugerah yang wajib dihormati, dijunjung tinggi dan dilindungi oleh negara, hukum, pemerintah, dan setiap orang demi kehormatan serta perlindungan harkat dan martabat manusia". ${ }^{9}$

Periodesasi perkembangan hak asasi manusia sebagai berikut; Periode Pertama, yang berkembang pada abad ke 17 dan 18, pada periode ini hak asasi manusia tertumpu pada hak sipil dan hak berpolitik. Pada periode kedua, yakni pada abad 19 hak asasi manusia lebih terfokus pada perlindungan terhadap hak ekonomi, sosial, dan budaya yang berakar dari tradisi kaum sosialis. Sementara pada periode ketiga hak asasi manusia mencakup hakhak solidaritas, yang merupakan rekonseptualisasi dari periode hak asasi manusia sebelumnya. Pada periode keempat hak asasi manusia tidak hanya dipahami dalam kontek hubungan vertical akan tetapi termaktub hubungan horizontal, yakni hubungan yang

\footnotetext{
${ }_{6}^{6}$ Moh Mahfud MD, Demokrasi dan Konstitusi di Indonesia, (Jakarta: Rineka Cipta, 2000), 29. 7 Jimly Asshidiqie, Pengantar Ilmu Hukum Tata Negara, (Jakarta: Rajawali Press, 20 I I), 343.

8 Mexsasai Indra, Dinamika Hukum Tata Negara Indonesia, (Bandung: Refika Aditama, 201 I), 167.

9 Lihat ketentuan Pasal I angka I Undang-undang Nomor 39 Tahun 1999 tentang Hak Asasi Manusia.
} 
selaras antara rakyat yang satu dengan yang lain, kelompok masyarakat yang satu dengan kelompok yang lain. ${ }^{10}$

Pengaturan mengenai hak asasi manusia di Indonesia sebagai negara hukum (rechsstaat), dimuat secara rigid dalam Konstitusi dan Undang Undang-undang Nomor 39 tahun 1999 tentang Hak Asasi Manusia. Terkait dengan hak untuk dipilih dan memilih secara implisit tercantum dalam pasal 27 ayat (1) dan Pasal 28 huruf D. Pasal 27 ayat (1) menentukan: "Segala warga negara bersamaan kedudukannya di dalam hukum dan pemerintahan dan wajib menjunjung hukum dan pemerintahan itu dengan tidak ada kecualinya". Pasal 28 huruf D ayat (3) menentukan: "Setiap warga negara berhak memperoleh kesempatan yang sama dalam pemerintahan."

Sedangkan dalam Undang-undang Nomor 39 Tahun 1999 tentang Hak Asasi Manusi mengatur mengenai hak untuk dipilih dalam Pasal 43 ayat (1) yang menyatakan;"setiap warga negara berhak untuk dipilih dan memilih dalam pemilihan umum berdasarkan persamaan hak melalui pemungutan suara yang langsung, umum, bebas, rahasia, jujur, dan adil sesuai dengan ketentuan peraturan perundang-perundanga". Lebih lanjut Ayat (3) menyebutkan "Setiap warga negara dapat diangkat dalam setiap jabatan pemerintahan". Dengan demikian, baik konstitusi maupun undang-undang telah memberikan pengakuan yang sama bagi setiap orang untuk dapat dipilih dalam pemilihan umum.

Pada dasarnya Undang-undang Nomor 39 Tahun 1999 tentang Hak Asasi Manusia memuat pengakuan yang cukup luas terhadap hak asasi manusia. Hak-hak yang dijamin di dalamnya mencakup pengakuan terhadap hak sipil dan hak berpolitik, hak ekonomi, sosial dan budaya serta pengakuan terhadap hak anak dan perempuan secara khusus dan hak masyarakat hukum adat (indegenous people). Dalam undang-undang iu disebutkan secara rinci mengenai hak asasi manusia sebagai hak yang bersifat kodrati dan melekat pada manusia.

10 Satya Arinanto dalam Mexasai Indra, Dinamika Hukum..., 170-171. 
Pengaturan hak asasi manusia dalam konstitusi dan Undangundang Nomor 39 Tahun 1999 dapat diklasifikasi sebagai berikut: Pertama, hak yang terkait hak sipil, meliputi hak untuk hidup, hak untuk terlepas dari penyiksaan, dan hak terbebas dari unsur perbudakan; kedua, hak yang terkait politik, ekonomi, sosial dan budaya, hak ini meliputi hak untuk berserikat, berkumpul, dan menyatakan pendapat; hak untuk memilih dan dan dipilih, hak untuk menduduki jabatan publik; ketiga, hak yang terkait dengan hak khusus dan hak pembangunan, hak ini meliputi hak atas kesetaraan gender, hak reproduksi untuk perempuan, dak atas lingkungan hidup yang baik dan sehat; keempat, pengaturan yang terkait dengan tanggungjawab Negara dan kewajiban asasi manusi, dalam kelompok ini diatur mengenai kewajiban manusia untuk menghormati hak orang lain, kewajiban setiap manusia untuk tunduk pada pembatasan undang-undang, sementara Negara bertanggungjawab untuk memajukan dan menjamin penegakan hak asasi manusia. ${ }^{11}$

\section{Pengaturan Hak Politik Mantan Narapidana Korupsi dalam Pemilu.}

Pada dasarnya, hak politik setiap orang untuk berpartisipasi dalam peilihan umum dijamin oleh konstitusi dan peraturan perundang-undangan, tidak terkecuali hak mantan terpidana korupsi untuk mencalonkan diri dalam pemilihan umum. Pengaturan mengenai hak politik mantan terpidana korupsi untuk mencalonkan diri dalam pemilihan umum dapat diklasifikasikan sebagai berikut:

Pertama, dalam Undang-undang Nomor 8 Tahun 2015 tentang Perubahan atas Undang-undang Nomor 1 Tahun 2015 tentang Penetapan Peraturan Pemerintah Pengganti Undang-undang Nomor 1 Tahun 2014 Tentang Pemilihan Gubernur, Bupati, dan Walikota menjadi Undang-Undang. Pasal 7 huruf g mengatur bahwa salah satu syarat untuk dapat mencalonkan diri sebagai

II Jimly Assidiqie, Pengantar IImu..., 364.

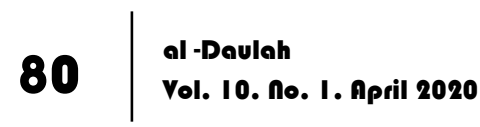


Calon Gubernur, Wakil Gubernur, Calon Bupati, Wakil Bupati, Calon Walikota atau Wakil Walikota adalah; "tidak pernah dijatuhi pidana penjara berdasarkan putusan pengadilan yang telah memperoleh kekuatan hukum tetap karena melakukan tindak pidana yang diancam dengan pidana penjara 5 (lima) tahun atau lebih;" Pasal 7 huruf g di atas yang mensyaratkan calon gubernur, bupati, walikota tidak pernah mendapatkan hukuman penjara karena melakukan tindak pidana yang diancam dengan hukuman 5 tahun penjara merupakan norma yang membatasi mantan terpidana korupsi untuk mencalonkan diri baik sebagai calon gubernur, wakil gubernur, bupati, wakil bupati, walikota atau wakil wali kota. Kemudian Pasal tersebut diuji materi (Judicial Review) ke Mahkamah Konstitusi oleh Jumanto dan Fathor Rosyid. Putusan MK mengabulkan sebagian gugatan dari Jumanto dan Fathor Rosyid, sehingga Pasal 7 Huruf g Undang-undang Nomor 8 Tahun 2015 tentang Perubahan atas Undang-undang Nomor 1 Tahun 2015 tentang Penetapan Peraturan Pemerintah Pengganti Undang-undang Nomor 1 Tahun 2014 Tentang Pemilihan Gubernur, Bupati, dan Walikota menjadi Undang-Undang, dinyatakan tidak berlaku dan tidak mempunyai kekuatan hukum mengikat.

Dasar pertimbangan Mahkamah Konstitusi membatalkan Pasal 7 huruf $g$ di atas adalah antara lain sebagai berikut: Pertimbangan pertama, norma yang terdapat dalam Pasal 7 huruf $g$ Undang-undang Nomor 8 Tahun 2015 tersebut merupakan bentuk pengurangan hak atas kehormatan, yang dapat dipersamakan dengan pencabutan hak-hak tertentu. Dalam arti seseorang yang pernah dihukum karena melakukan tindak pidana korupsi tidak akan dapat mencalonkan diri sebagai calon kepala daerah dalam pemilihan umum, dengan demikian artinya hak untuk mencalonkan diri secara normatif telah dicabut oleh ketentuan undang-undang. Padahal berdasarkan Pasal 35 ayat 1 angka 3 KUHP bahwa yang dapat mencabut hak seseorang adalah putusan hakim. Dengan demikian, pencabutan hak pilih seseorang hanya dapat dilakukan dengan putusan hakim sebagai hukuman 
tambahan, bukan oleh ketentuan undang-undang. ${ }^{12}$ Pertimbangan kedua, Mahkamah Konstitusi dalam Putusan Nomor 4/PUUVII/2009, telah memberi syarat terhadap mantan narapidana korupsi yang telah menjalani hukuman, yang akan mencalonkan diri sebagai kepala daerah untuk mengumumkan secara terbuka di hadapan umum bahwa yang bersangkutan pernah dijatuhi pidana penjara, hal ini diperlukan agar rakyat atau para pemilih mengetahui keadaan yang bersangkutan. Apabila mantan narapidana korupsi telah memenuhi syarat tertentu tersebut, maka seharusya tidak boleh lagi mendapatkan hukuman tambahan berupa pelarangan untuk mencalonkan diri, kecuali ia menguali perbuatanya. Pertimbangan ketiga, bahwa Mahkamah Konstitusi melalui putusan No. 4/PUU-VII/2009 telah memberikan ruang kepada mantan narapidana untuk proses melakukan penyesuain diri dengan masyarakat, minimal lima tahun setelah menjalani hukuman. Apabila mantan narapidana korupsi telah menjalani hukuman, menyesali perbuatannya dan telah hidup bermasyarakat minmal lima tahun, maka tidak sepatutnya untuk mendapatkan hukuman tambahan sebagimana yang diatur dalam Pasal 7 huruf $g$ Undang-undang Nomor 8 Tahun 2015, yakni dilarang mencalonkan diri sebagai calon kepala daerah dalam pemilihan umum. ${ }^{13}$

Kedua, Undang-undang Nomor 7 Tahun 2017 tentang Pemilihan Umum, dalam undang-undang ini pengaturan mengenai hak politik mantan terpidana korupsi diatur dalam Pasal 182 ayat (1) yang menyatakan bahwa: "mantan narapidana korupsi yang telah menjalani masa hukuman selama lima tahun atau lebih, boleh mencalonkan diri selama yang bersangkutan mengumumkan pernah berstatus sebagai narapidana kepada publik". Dengan demikian berdasarkan ketentuan Pasal 182 ayat (1) Undang-undang Nomor 7 Tahun 2017, mantan terpidana korupsi boleh mencalonkan diri sebagai anggota legislatif, jika telah menjalani hukuman, dan mengumumkan kepada publik bahwa ia pernah menjadi narapidana korupsi dan telah menjalani hukuman.

\footnotetext{
${ }^{12}$ Lihat Putusan Mahkamah Konstitusi Nomor 42/PUU-XII/20 I5.

${ }^{13} \mathrm{lbid}$.
} 
Undang-undang Nomor 7 tahun 2017 tentang Pemilihan Umum ini sejalan dengan putusan Mahkamah Konstitusi Nomor 42/PUU-XII/2015 yang memberikan ruang bagi mantan narapidana korupsi untuk mencalonkan diri dalam pemilihan umum, apabila yang bersangkutan telah menjalani hukuman, sudah beradaptasi dengan masyarakat selama 5 tahun, dan mengumumkan kepada publik bahwa ia pernah menajalani hukuman karena melakukan tindak pidana korupsi.

Kemunculan Undang-undang No. 7 Tahun 2017 tentang Pemilihan Umum seolah tidak mengurangi hak politik mantan terpidana korupsi dalam pemilu. Namun demikian upaya pengurangan hak politik mantan narapidana korupsi muncul kembali dalam Peraturan Komisis Pemilihan Umum (PKPU) Nomor 20 Tahun 2018. Dalam Pasal 4 yang mengatur mengenai tata cara pengajuan calon yang dilakukan oleh partai politik. Dalam ayat 1 misalnya disebutkan; "Partai Politik dalam mengajukan bakal calon anggota DPR, DPRD Provinsi, dan DPRD Kabupaten/Kota mempunyai hak, kesempatan, dan menerima pelayanan yang setara berdasarkan Peraturan perundang-undangan." Kemudian pada ayat 2 dijelaskan; "Setiap Partai Politik melakukan seleksi bakal calon anggota DPR, DPRD Provinsi, dan DPRD Kabupaten/Kota secara demokratis dan terbuka sesuai dengan AD dan ART, dan/atau peraturan internal masing-masing Partai Politik".

Problematika hukum kemudian muncul di dalam ayat 3 yang menjelaskan, bahwa: "Dalam seleksi bakal calon secara demokratis dan terbuka sebagaimana dimaksud pada ayat (2), tidak menyertakan mantan terpidana bandar narkoba, kejahatan seksual terhadap anak, dan korupsi". Berdasarkan ketentuan Pasal 4 ayat 3 di atas, termuat secara explisit adanya larangan bagi partai untuk mendaftarkan kadernya yang berstatus mantan terpidana bandar narkoba, kejahatan seksual terhadap anak, dan korupsi sebagai bakal calon anggota DPR, DPRD Provinsi, dan DPRD Kabupaten/Kota.

Klausul yang terkandung di dalam pasal 4 ayat 3 di atas, dirasa diskriminatif. Penilaian diskriminatif itu direspon oleh Jumanto 
dengan mengajukan permohonan pembatalan ke Mahkamah Agung, dengan ketua KPU RI sebagai termohon. ${ }^{14}$ Dalam permohonan tersebut pemohon mengajukan permohonan hak uji materiil (yudicial review), terhadap Peraturan Komisi Pemilihan Umum Republik Indonesia Nomor 20 Tahun 2018 tentang Pencalonan Anggota Dewan Perwakilan Rakyat, Dewan Perwakilan Rakyat Daerah Provinsi, Dewan Perwakilan Rakyat Daerah Kabupaten/Kota.

Berdasarkan permohonan Jumanto tersebut kemudian Mahkamah Agung membatalkan norma yang melarang mantan terpidana korupsi untuk mencalonkan diri sebagai anggota legislatif. Menurut Mahkamah Agung pasal 4 ayat (3) tersebut bertentangan dengan peraturan perundang-undangan yang lebih tinggi, yaitu dengan Undang-Undang Nomor 7 Tahun 2017 tentang Pemilihan Umum juncto Undang-Undang Nomor 12 Tahun 2011 tentang Pembentukan Peraturan Perundang-undangan, karenanya tidak mempunyai kekuatan hukum mengikat dan tidak berlaku umum. ${ }^{15}$

Dasar pertimbangan Mahkamah Agung membatalkan Pasal 4 ayat (3) PKPU No. 20 Tahun 2018 antara lain sebagai berikut:

Bahwa hak memilih dan dipilih sebagai anggota legislatif merupakan hak dasar di bidang politik dan dijamin oleh konstitusi Pasal 28 UUD NRI Tahun 1945. Pengakuan hak politik ini juga diakui dalam Kovenan Internasional Hak-hak Sipil dan Politik (International Covenant on Civil and Political Rights). Selanjutnya hak politik juga diatur dalam Pasal 43 ayat (1) Undang-undang Nomor 39 Tahun 1999 tentang Hak Asasi Manusia, yang menyatakan;" setiap warga negara berhak untuk dipilih dan memilih dalam pemilihan umum berdasarkan persamaan hak melalui pemungutan suara yang langsung, umumu, bebas, rahasia, jujur, dan adil sesuai dengan ketentuan peraturan perundang-undangan. Dalam Pasal 73 Undang-undang Nomor 39 Tahun 1999 juga disebutkan :hak dan kebebasan yang diatur oleh undang-undang ini hanya dapat

\footnotetext{
${ }^{14}$ Salinan Putusan Mahkamah Agung Nomor 46 P/HUM/20 I 8 Tahun 2018

15 Salinan Putusan Mahkamah Agung Nomor 46 P/HUM/20 8 Tahun 20 I 8, hlm. 74.
} 
dibatasi oleh dan berdasarkan undang-undang, semata-mata untuk menjamin pengakuan dan penghormatan terhadap hak asasi manusia serta kebebasan dasar orang lain, kesusilaan, ketertiban umum, dan kepentingan bangsa."

Bahwa berdasarkan Undang-undang HAM di atas sangat jelas diatur bahwa setiap warga negara mempunyai hak yang sama untuk dipilih dan memilih dalam pemilihan umum dan jika ada pembatasan terhadap hak tersebut, maka harus ditetapkan dalam undang-undang, atau berdasarkan putusan hakim yang mencabut hak politik seseorang sebagai hukuman tambahan.

Bahwa norma yang terdapat dalam Peraturan Komisi Pemilihan Umum Nomor 20 Tahun 2018 Pasal 4 ayat (3) bertentangan dengan Pasal 240 ayat (1) huruf g Undang-undang Nomor 7 Tahun 2017 tentang Pemilihan Umum, yang menyatakan:"bahwa calon anggota DPR, DPRD Propinsi, dan DPRD Kabupaten/kota adalah warga negara Indonesai dan harus memenuhi persyaratan; (a). Tidak pernah dipidana penjara berdasarkan putusan pengadilan yang telah memperoleh kekuatan hukum tetap karena melakukan tindak pidana yang diancam dengan pidana penjara 5 (lima) tahun, atau lebih, kecuali secara terbuka dan jujur mengemukakan kepada publik bahwa yang bersangkutan mantan terpidana."

Bahwa dari ketentuan Pasal 240 ayat (1) huruf g tersebut tidak ada norma atau aturan larangan mencalonkan diri bagi mantan terpidana korupsi sebagaiamana yang tercantum dalam pasal 4 ayat (3), Pasal 11 ayat (1) huruf d dan lampiran model B.3 Pakta Integritas Pengajuan Bakal Calon Anggota DPR/DPRD Propinsi/DPRD Kabupaten/Kota, Peraturan Komisi Pemilihan Umum Nomor 20 Tahun 2018. ${ }^{16}$

${ }^{16}$ Salinan Putusan Mahkamah Agung Nomor 46 P/HUM/20I8, hlm 72. 
Implementasi Hak Politik Mantan Terpidana Korupsi dalam Pemilu 2019 di Jawa Timur

Penjelasan sebelumnya telah cukup gamblang mengenai aturan hukum hak politik mantan terpidana korupsi, khususnya berkaitan dengan partisipasi politik dalam pemilu, terutama sebagai peserta pemilu. Berbagai upaya untuk mengamputasi dan atau membatasi hak politik mantan terpidana korupsi tidak berhasil dalam norma peraturan perundang-undangan, hal tersebut dapat dilihat dari historis pembatasan hak politik mantan narapidana korupsi dalam peraturan perundang-undangan yang kemudian dibatalkan oleh Mahkamah Konstitusi, dan Mahkamah Agung. Sehingga secara normatif mantan terpidana korupsi berhak mencalonkan diri sebagai calon legislatif dalam Pemilu Tahun 2019, jika dilihat dari data yang dilansir oleh KPU Pusat terdapat beberapa calon legislatif yang berasal dari berbagai partai politik yang berstatus mantan terpidana korupsi baik untuk calon anggota DPRD maupun calon anggota DPD.

Berikut daftar partai politik yang mencalonkan mantan terpidana korupsi sebagai calon anggota DPRD Provinsi dan DPRD Kabupaten/Kota di seluruh Indonesia adalah sebagai berikut: ${ }^{17}$

Tabel 1: Daftar Partai Politik Yang Mencalonkan Mantan Terpidana Korupsi sebagai calon DPRD Prop/DPRD Kab dalam Pemilu 2019

\begin{tabular}{|l|l|l|l|l|}
\hline No. & Nama Partai Politik & $\begin{array}{l}\text { Caleg DPRD } \\
\text { Propinsi }\end{array}$ & $\begin{array}{l}\text { Caleg DPRD } \\
\text { Kab/Kota }\end{array}$ & Jumlah \\
\hline 1 & Partai Geridra & 3 orang & 3 orang & 6 orang \\
\hline 2 & PDIP & 1 orang & - & 1 orang \\
\hline 3 & Partai Golkar & 4 orang & 4 orang & 8 orang \\
\hline 4 & Partai Garuda & - & 2 orang & 2 orang \\
\hline 5 & Partai Berkarya & 2 orang & 2 orang & 4 orang \\
\hline 6 & PKS & - & 1 orang & 1 orang \\
\hline 7 & Partai Perindo & 1 orang & 1 orang & 2 orang \\
\hline 8 & PAN & 1 orang & 3 orang & 4 orang \\
\hline 9 & Partai Hanura & 3 orang & 2 orang & 5 orang \\
\hline
\end{tabular}

${ }^{17}$ Humas KPU, 30 Januari 2019, www.kpu.o.id 


\begin{tabular}{|l|l|l|l|l|}
\hline 10 & Partai Demokrat & - & 4 orang & 4 orang \\
\hline 11 & PBB & 1 orang & - & 1 orang \\
\hline 12 & PKPI & - & 2 orang & 2 orang \\
\hline & Total & $\mathbf{1 6}$ orang & $\mathbf{2 4}$ orang & $\mathbf{4 0}$ orang \\
\hline
\end{tabular}

Berdasarkan tabel di atas jumlah calon legislatif mantan terpidana korupsi untuk calon DPRD Propinsi sejumlah 16 orang, DPRD Kabupaten/Kota sejumlah 24 orang, sehingga jumlah total caleg mantan terpidana korupsi pada pemilu 2019 sejumlah 40 orang. Dengan rincian dari Partai Gerindra sejumlah 6 orang PDIP sejumlah 1 orang, Parta Golkar 8 orang, Partai Garuda 2 orang, Parta Berkarya 4 orang, PKS sejumlah 1 orang, Partai Perindo sejumlah 2 orang, PAN sejumlah 4 orang, Partai Hanura sejumlah 5 orang, Partai Demokrat sejumlah 4 orang, Partai PBB sejumlah 1 orang, PKPI sejumlah 2 orang, dari jumlah Partai yang ikut Pemilu tahun 2019 ada 4 partai politik yang tidak mencalonkan kadernya yang bestatsu mantan terpidana korupsi, yaitu Partai Nasdem, Partai Kebangkitan Bangsa, Partai Solidaritas Indonesia, dan Partai Persatuan Pembangunan.

Adapun jumlah mantan terpidana korupsi yang mencalonkan diri sebagai anggota Dewan Perwakilan Daerah (DPD) adalah sebagai berikut: ${ }^{18}$

Tabel 2: Daftar Mantan Terpidana Korupsi yang Mencalonkan Diri sebagai Anggota DPD dalam Pemilu 2019

\begin{tabular}{|l|l|}
\hline Daerah Pemilihan & Jumlah \\
\hline DPD Prov. Aceh & 1 orang \\
\hline DPD Prov. Sumatra Utara & 1 orang \\
\hline DPD Prov. Bangka Belitung & 1 orang \\
\hline DPD Prov. Sumatra Selatan & 1 orang \\
\hline DPD Prov. Kalimantan Tengah & 1 orang \\
\hline DPD Prov. Sulawesi Tenggara & 3 orang \\
\hline DPD Prov. Sulawesi Utara & 1 orang \\
\hline Jumlah Total & 9 orang \\
\hline
\end{tabular}

$18 \mathrm{lbid}$. 
Berdasarkan tabel di atas rekap calon legislatif yang berstatus mantan terpidana korupsi dalam Pemilu tahun 2019 dengan rincian sebagai berikut: DPD 9 orang, DPRD Propinsi 16 orang DPRD Kabupaten 24 orang, dari total jumlah tersebut calon mantan terpidana korupsi yang mencalonkan diri sebagai calon DRPD di Jawa Timur hanya 1 orang yaitu di Kabupaten Blitar. Dengan demikian meskipun secara normatif diperbolehkan oleh Undangundang namun dalam kenyataannya beberapa partai politik di Jawa Timur tidak mencalonkan anggotanya yang merupakan mantan terpidana dalam kasus korupsi. Hal tersebut sebagaimana diungkapkan oleh M. Arbayanto, Devisi Hukum dan Pengawasan bahwa meskipun secara normatif mantan terpidana korupsi diberikan hak untuk mencalonkan diri sebagai anggota legislatif, akan tetapi khusus di Jawa Timur hampir tidak ada mantan terpidana korupsi yang mencalonkan diri sebagai anggota legislatif dalam Pemilu 2019 kecuali di Kabupaten Blitar. Sejak KPU mengeluarkan Peraturan KPU No. 20 Tahun 2018 yang melarang mantan terpidana korupsi untuk mencalonkan diri sebagai anggota legislatif banyak partai politik yang membatalkan pencalonan kadernya yang pernah terlibat kasus korupsi.

Menurut M. Arbayanto Peraturan KPU tersebut sebenarnya sebagai upaya preventif atau pencegahan terhadap tindak pidana korupsi yang dilakukan oleh anggota legislatif, karena selama ini KPK dalam banyak hal lebih pada aspek penindakan terhadap pelaku tindak pidana korupsi. Meskipun Peraturan KPU tersebut dibatalkan oleh Mahkamah Agung karena dianggap bertentangan dengan Undang-undang Pemilu. ${ }^{19}$

Menyikapi pembatalan Peraturan KPU tersebut beberapa pengurus partai politik mempunyai pendapat yang berbeda, sebagaimana diungkapkan oleh Saim, Ketua DPC PDIP Kabupaten Lamongan sebagai berikut:"Melarang mantan terpidana korupsi untuk mencalonkan diri sebagai anggota DPRD adalah

${ }^{19}$ M. Arbayanto, Wawancara, I Nopember 2019. 
bertentangan dengan undang-undang dan konstitusi yang membolehkan kepada setiap orang untuk dipilih dan memilih, melarang mantan terpidana korupsi untuk mencalonkan diri sebagai anggota legiaslatif juga bertentangan dengan nilai keadilan yang harus dijunjung tinggi oleh setiap orang. Mantan terpidana korupsi yang telah menjalani hukuman pidananya sudah dianggap cukup mendapatkan punishment tanpa harus ditambah dengan punisment tambahan yakni dengan larangan untuk mencalonkan diri sebagai anggota legislatif setelah bebas dari hukuman, kacuali hak pilihnya dicabut oleh putusan hakim. Namun demikian sebagai upaya preventif terhadap tindak pidana korupsi kebijakan di partai PDIP bahwa apabila ada kader yang terkena kasus korupsi maka kader yang terkena kasus korupsi dipecat dari keanggotaan partai, dengan demikian secara otomatis dalam pemilu 2019 tidak ada kader partai PDIP yang berstatus mantan terpidana korupsi yang mencalonkan diri sebagai anggota legislatif di Lamongan Jawa Timur." 20

Hal senada juga disampaikan oleh Kasdono, anggota DPRD Kabupaten Lamongan dari Fraksi PKB sebagai berikut:"larangan yang dituangkan oleh KPU dalam Peraturan KPU No. 20 Tahun 2018 merupakan suatu hal yang dilematis pada satu sisi hak mantan terpidana korupsi untuk mencalonkan diri sebagai anggota DPR/DPRD tidak boleh dilarang kecuali ditentukan secara tegas oleh Undang-undang dan Konstitusi, pada sisi yang lain semangat untuk memberantas korupsi juga harus tetap dilaksanakan pada sisi inilah sehingga KPU membuat peraturan yang melarang mantan terpidana korupsi untuk mencalonkan diri sebagai anggota legislatif. Pada dasarnya secara pribadi saya juga tidak setuju dengan peraturan KPU tersebut, karena hak dasar seseorang untuk memlih dan dipilih dijamin oleh konstitusi. Pembatasan terhadap mantan terpidana korupsi untuk mencalonkan diri sebagai perbuatan yang bertentangan dengan konstitusi. Jika ada mantan terpidana korupsi biarkan mencalonkan diri toh yang akan

20 Saim, Wawancara, 27 Agustus 2019. 
menentukan terpilih atau tidaknya adalah masyarakat melalui seleksi alamiah. Namun demikian kebijakan yang diambil oleh partai ketika ada kader yang terkena kasus korupsi tidak akan mendapatkan bantuan hukum, dan apabila terbukti bersalah melalui putusan hakim yang bersifat incraht maka akan dilakukan pemecatan, dengan demikian seara otomatis tidak akan dapat mencalonkan diri sebagai anggota legislatif pada pemilu berikutnya. Oleh karena itu dalam pemilu 2019 tidak ditemukan calon dari PKB yang merupakan mantan terpidana korupsi baik di Lamongan, Jawa timur maupun di wilayah lain di seluruh Indonesia. ${ }^{21 B e r d a s a r k a n ~ d a t a ~ y a n g ~ d i r i l i s ~ o l e h ~ K P U ~ P u s a t ~ a d a ~}$ empat partai yang konsisten tidak mencalonkan mantan narapidana korupsi dalam Pemilu 2019 yaitu PKB, Nasdem, PPP, dan PSI. 22

Dalam perspektif hukum dan HAM pembatasan hak politik warga negara untuk mencalonkan diri sebagai anggota legislatif tidak selayaknya diatur dalam Peraturan KPU, karena secara normatif Undang-undang Pemilu memperbolehkan mantan terpidana korupsi untuk mencalonkan diri sebagai anggota legislatif, pembatasan hak politik warga negara untuk mencalonkan diri sebagai anggota legislatif hanya bisa dilakukan oleh putusan hakim, sepanjang putusan hakim tidak melarang mantan terpidana korupsi untuk mencalonkan diri, maka peraturan perundangundangan dan peraturan KPU tidak selayaknya untuk melarang.

\section{Penutup}

Hak politik mantan terpidana korupsi dijamin di dalam Konstitusi Pasal 28 huruf D ayat 3 UUD NRI Tahun 1945 bahwa, setiap orang berhak memperoleh kesempatan yang sama dalam pemerintahan. Juga di dalam Dalam pasal 43 Undang-undang No. 39 tahun 1999 tentang Hak Asasi Manusia dijelaskan bahwa Setiap warga negara berhak untuk dipilih dan memilih dalam pemilihan

\footnotetext{
${ }^{21}$ Kasdono, wawancara, 15 September 2019.

22 Nurrahman, "Caleg Mantan Napi Korupsi dan Paradoks Demokrasi,"Beritatagar.id, Jumat, 08 Pebruari 2019. lihat juga Humas, KPU, 30 Januari 2019. mww.kpu.go.id
} 
umum berdasarkan persamaan hak melalui pemungutan suara yang langsung, umum, bebas, rahasia, jujur, dan adil sesuai dengan ketentuan peraturan perundang-undangan. Pembatasan hak politik mantan terpidana korupsi dalam Peraturan KPU No. 20 Tahun 2019 secara normatif bertentangan dengan peraturan yang di atasnya, yakni Konstitusi, Undang-undang Hak Asasi Manusia, dan Undang-undang Pemilu.

Secara konstitusional pembatasan hak politik mantan terpidana korupsi yang dituangkan dalam peraturan KPU memang tidak bisa dibenarkan karena bertentangan dengan Kostitusi, Undang-undang pemilu dan Undang-undang Hak Asasi Manusia. Namun dalam implementasi di lapangan sebagian besar partai politik tetap mencalonkan kadernya yang pernah menjadi terpidana kasus korupsi, hanya sebagian kecil partai politik yang konsisten tidak mencalonkan kadernya yang berstatus mantan terpidana korupsi. Pertimbangan yang mendasarinya adalah dalam rangka upaya preventif atau pencegahan terhadap tindak pidana korupsi.

\section{Daftar Pustaka}

Zazili, Ahmad. "Pengakuan Negara Terhadap Hak-hak Politik (Rigth to Vote) Masyarakat Adat Dalam Pelaksanaan Pemilihan Umum". Jurnal Konstitusi Vol 9 Nomor 1, Maret 2012.

Et all, Bisarida, “Komparasi Mekansime Penyelesaian Sengketa Pemilu di Beberapa Negara Penganut Paham Demokrasi", Jurnal Konstitusi, Volume 9, Nomor 3, September 2012.

Thaib, Dahlan. Implementasi Sistem Ketatanegaraan Menurut UUD 1945. Yogyakarta, Pustaka Pelajar, 1993.

Asshidiqie, Jimly. Pengantar Ilmu Hukum Tata Negara. Jakarta: Rajawali Press, 2011.

Mahfud MD, Moh. Demokrasi dan Konstitusi di Indonesia. Jakarta: Rineka Cipta, 2000.

Indra, Mexsasai. Dinamika Hukum Tata Negara Indonesia. Bandung: Refika Aditama, 2011. 
Budiardjo, Mirriam. Dasar-dasar Ilmu Politik. Jakarta: Gramedia Pustaka, 2009.

Soekanto, Soerjono. Pengantar Penelitain Hukum. Jakarta: PT. Raja Grafindo, 2004.

Putusan Mahkamah Konstitusi No.42/PUU-XIII/2015.

Putusan Mahkamah Agung Nomor 46 P/HUM/2018 Tahun 2018

Humas KPU. 30 Januari 2019. www.kpu.o.id

Nurrahman. Caleg Mantan Napi Korupsi dan Paradoks Demokrasi. Beritatagar.id. Akses Jumat, 08 Februari 2019.

Arbayanto, M. Wawancara. 1 Nopember 2019.

Saim. Wawancara. 27 Agustus 2019.

Kasdono. Wawancara. 15 September 2019. 